\title{
Structural Diversity of Mercury (II) Complexes Derived from Substituted Pyrazoles
}

Indranil Chakraborty, Shambhu Kandel and Raphael G. Raptis* Department of Chemistry and Biochemistry

Florida International University, Miami, FL 33199

This work stemmed from our interest in suitable pyrazole-based extractants for removal of both organic and inorganic mercury from low-level nuclear waste (LLW) at the Savannah River Site (SRS). In our exploration we have examined reactions of several substituted pyrazoles with $\mathrm{Hg}(\mathrm{II})$ salts, such as $\mathrm{HgCl}_{2}$ and $\mathrm{Hg}\left(\mathrm{CH}_{3} \mathrm{COO}\right)_{2}$. In general, pyrazole derived complexes are quite stable and the 3-, 4-, and 5-positions on this heterocyclic ligand offers the amenability for functionalization with different groups, which dictates the structural diversity and properties of the resulting complexes. Herein we describe the synthesis and crystal structures of $\mathrm{Hg}$ (II) pyrazole/pyrazolato complexes prepared under acidic or basic conditions. Due to the varying steric and electronic properties of the pyrazoles employed here, dinuclear and polymeric $\mathrm{Hg}$ (II) complexes have been isolated: $\left[\mathrm{Hg}_{2} \mathrm{Cl}_{2}\left(3,5-\mathrm{Me}_{2}-4-\mathrm{NO}_{2}-\mathrm{pz}\right)_{3}\right] \quad(\mathbf{1}), \quad[\mathrm{Hg}(\mu-\mathrm{Cl}) \mathrm{Cl}(4-\mathrm{I}-\mathrm{pzH})]_{\mathrm{n}} \quad$ (2), $\left[\mathrm{Hg}(\mu-\mathrm{Cl})_{2}(4-\mathrm{I}-\mathrm{pzH})\right]_{\mathrm{n}}(3),\left[\mathrm{Hg}_{2}\left(\mathrm{CH}_{3} \mathrm{COO}\right) \mathrm{Cl}_{2}\left(3-\mathrm{NO}_{2}-\mathrm{pz}\right)\right]_{\mathrm{n}}(4),\left[\mathrm{HgCl}\left(\mu-4-\mathrm{NO}_{2}-3,5-\mathrm{Me}_{2}-\right.\right.$ pz) $]_{\mathrm{n}} \quad(\mathbf{5}), \quad\left[\mathrm{Hg}\left(\mathrm{CH}_{2} \mathrm{COCH}_{3}\right)\left(4-\mathrm{NO}_{2} \text {-bis(2,4-dinitrophenyl)pz) }\right]_{\mathrm{n}} \quad\right.$ (6), $\quad\left[\mathrm{HgCl}\left(2,4,6-\mathrm{Et}_{3}\right.\right.$ 1,3,5-tris(4-Ph-pz) $]_{\mathrm{n}}(7)$. In these complexes, all possible coordination numbers (from $\mathrm{CN}$ = 2 - 6) around $\mathrm{Hg}$ (II) centers have been encountered.
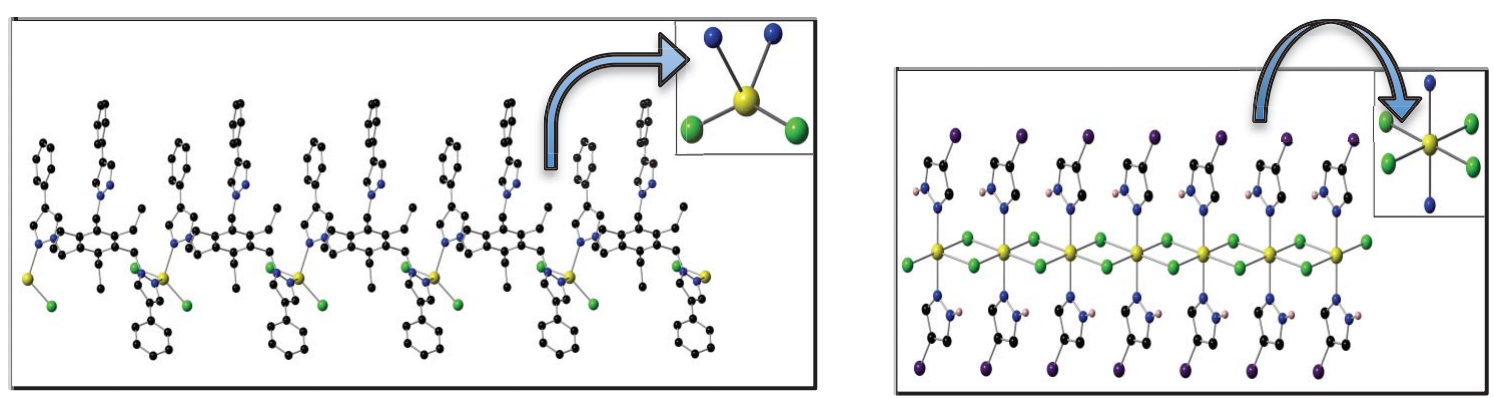